\title{
MARCAS COMERCIALES Y LA DEFENSA DE LA LIBRE COMPETENCIA (ANÁLISIS CRÍTICO DE LA JURISPRUDENCIA DE LOS ORGANISMOS ANTIMONOPOLIOS)
}

\author{
Eduardo Jequier Lehuedé
}

SUMARIO: I.- Introducción. II.- El D.L. 211 y la libre competeniza como bien juridico protegido. III.- Libre competencia y marcas comerciales en la normativa nacional. IV.- Una propuesta de solución; adecuación de la normativa sobre propiedad industrial a los acuerdos internacionales y medidas complementarias. V.- Conclusiones.

\section{I.- INTRODUCCIÓN.}

Toda tarea de investigación de fenómenos vivos y dinámicos, de aquellos que se generan y evolucionan simultáneamente con el proceso de análisis que espontáneamente van generando, presupone en los más de los casos múltiples dificultades y riesgos. Lo anterior, pues, en nada le es ajeno a la ciencia del derecho en cuanto expresión del conjunto de principios y reglas a que se someten las relaciones humanas en una sociedad civil, por esencia cambiantes en el tiempo y espacio. Cada época y cada sociedad ha engendrado, a lo largo de la historia, necesidades y conflictos particulares que el derecho, con alguna lentitud y en ocasiones a fuerza de tropiezos y desencuentros, ha debido necesariamente reconocer, asimilar y finalmente regular y perfeccionar.

Es tal vez en nuestra época actual, marcada por el avance vertiginoso e insospechado de la ciencia, el comercio y la técnica, donde el derecho se ha visto enfrentado a fenómenos y conflictos para los cuales muchas de las instituciones seculares del derecho civil y comercial resultan insuficientes y obsoletas. Uno de tales conflictos, pues, surgido a consecuencia del amplio desarrollo y globalización de las economías de mercado a nivel mundial, es el que hoy en dia se observa claramente en Chile respecto de dos ramas o áreas precisas del derecho, a saber: a) El Derecho de la Competencia y el ámbito de aplicación del D.L. N²11, de 1973; y b) El derecho de Propiedad Intelectual y, especificamente, el estatuto jurídico sobre marcas comerciales establecido en la Ley $\mathrm{N}^{\circ} 19.039$.

Por simple que sea el análisis crítico que se formule respecto de la aplicación e interpretación sistemática que actualmente se hace respecto de la normativa arriba

1 Abogado. Magister en Derecho de la Empresa, Pontificia Universidad Católica de Chile. Profesor de Derecho Económico, Escuela de Derecho de la Universidad Católica del Norte, sede Coquimbo. 
apuntada, resulta ya imposible obviar la compleja y hasta riesgosa realidad jurídica que se ha venido mostrando en el último tiempo en Chile. No son pocos los casos en que los organismos de la Libre Competencia han estimado necesario intervenir en el ámbito de la propiedad industrial y, específicamente, en materia de marcas comerciales y la normativa específica que las regula (hoy Ley $\mathrm{N}^{\circ} 19.039$ ), con el fin reiterado en cada ocasión- de prevenir o sancionar -según el caso- un acto que se estima contrario a la libre competencia. A pesar del estatuto de garantías y protección de que goza en Chile una marca comercial, consagrado incluso con rango constitucional, los antedichos organismos han privilegiado incluso -en cuanto bien jurídico protegido- la libre concurrencia entre los agentes y partícipes del mercado, por sobre los derechos que se le reconocen al titular de una marca comercial, legalmente registrada. Sin embargo, como resultado de la defensa a ultranza del antedicho bien jurídico y a consecuencia de una interpretación amplia y hasta ilimitada de la normativa para la defensa de la libre concurrencia por parte de las Comisiones, se ha llegado también a poner en serio peligro instituciones y principios jurídicos de no menor relevancia en un estado de derecho, lo que lleva necesariamente a plantear una revisión y redefinición del marco preciso en que aquella debe insertarse.

Por lo anterior ( $y$ en el entendido de que las Comisiones -Preventivas y Resolutiva- han actuado en aquellos casos en que consideran que el titular de una marca comercial ha ejercido los derechos subsecuentes desnaturalizando el fin para el cual fueron concebidos), se persigue con este trabajo de investigación el proponer alternativas de solución que, armonizando las normativas en disputa y precisando los bienes jurídicos en juego, permitan la plena y correcta aplicación de aquellas, sin imponer la una sobre la otra en base-muchas veces- a presunciones y/o conjeturas que pudieren resultar aventuradas.

En sintesis, siendo la infracción contemplada en el D.L. 211 un verdadero delito (según lo ha dicho la Excma. Corte Suprema), se hace necesario entonces que la imposición de aquella obedezca a antecedentes y elementos de convicción concretos y contundentes, de manera tal que los derechos que se derivan de una marca comercial válidamente registrada -y en tanto conserve tal carácter- no sean preteridos en base a concepciones subjetivas. Pero a la vez, deberá dejarse en claro la imposibilidad de privilegiar a quien utiliza la legislación marcaría con fines de dudosa ética comercial (lo que se presenta también como una realidad indiscutible). De aquí entonces la necesidad de buscar soluciones que permitan satisfacer ambos propósitos, de una manera armónica y jurídicamente complementaria. 


\section{II.- EL D.L. 211 Y LA LIBRE COMPETENCIA COMO BIEN JURÍDICO PROTEGIDO.}

\section{1.- Del bien jurídico protegido en la normativa antimonopolios.}

1.1.- El Decreto Ley 211, de 1973, regula orgánicamente el sistema de defensa de la libre competencia en nuestro país. Para estos efectos, en su artículo $1^{\circ}$ establece el delito monopólico, entendido como la ejecución o celebración de todo hecho, acto o convención que tienda a impedir la libre competencia dentro del país en las actividades económicas. Por su parte, el artículo $2^{\circ}$ señala algunas conductas que para los efectos del artículo $1^{\circ}$ se consideran como actos que tienden a impedir la libre competencia. En fín, el artículo $6^{\circ}$ señala que "para la prevención, investigación, correción y represión de los atentados a la libre competencia o de los abusos en que incurra quien ocupe una situación monopólica, aun iuando no fueren constitutivos de delito, habrá los siguientes organismos y servicios"... (que se enumeran). A continuación, el D.L. 211 regula la organización, atribuciones y procedimiento de las cuatro clases de órganos de defensa de la libre competencia.

Precisando acerca del contenido y finalidad de la normativa antimonopolios, la Comisión Resolutiva ha señalado:

"SEGUNDO: Que la finalidad de la legislación antimonopolios, contenida en el cuerpo legal citado, no es solo la de resguardar el interés de los consumidores sino más bien la de salvaguardar la libertad de todos los agentes de la actividad económica, sean ellos productores, comerciantes o consumidores, en el fin último de beneficiar la colectividad toda, dentro de la cual, por cierto, tienen los consumidores importante papel. En otras palabras, el bien jurídico protegido es el interés de la comunidad de que se produzcan más y mejores bienes y se presten más y mejores servicios a precios más convenientes, lo que se consigue asegurando la libertad de todos los agentes económicos que participan en el mercado.

"TERCERO: Que el Decreto Ley 211 cumple, así, una trascendente función social, de alto interés nacional, ya que dice relación con la satisfacción de las necesidades vitales de las personas, para lo cual, velando por el bien común, crea adecuadas condiciones económico-sociales en el mercado, las que se alcanzan con una sana y efectiva competencia.

"CUARTO: Que, como lo expresa el considerando segundo del Decreto Ley $\mathrm{N}^{\circ} 211$, las actividades contrarias a esta sana y efectiva competencia no incentivan la producción, protegen al productor o distribuidor ineficiente, tienden a la concentración del poder económico y distorsionan el mercado en perjuicio de la colectividad.

"QUINTO: Que la libre competencia, en cambio asegura a todas las personas, con igualdad de oportunidades, el derecho a desarrollar cualquier actividad económica que no sea contraria a la moral, al orden público o a la 
seguridad nacional, respetando las normas legales que la regulen, derecho que garantiza explícitamente el artículo $19 \mathrm{~N}^{\circ} 21$ de la Carta Fundamental;

"SEXTO: Que una de las normas de mayor importancia que regulan esta garantía constitucional y que forman parte del llamado Orden Público Económico es, precisamente, el Decreto Ley 211, ya que sus disposiciones tienen por objeto evitar la distorsión de la economía a que puede conducir la manipulación de la oferta y la demanda en el mercado;

"SÉPTIMO: Que de lo dicho en el considerando anterior y de lo prescrito en la garantía constitucional citada, se desprende que cualquiera que sea la actividad económica que ejerzan una o más personas individualmente o constituidas en alguna forma de asociación, ésta debe someterse necesariamente a las disposiciones legales que la regulen y, entre ellas, muy especialmente a los preceptos del Decreto Ley 211, los que por cumplir una finalidad de alto interés nacional son de orden público y no pueden ser alterados, modificados o sustituidos por la voluntad de las personas que intervienen en ella...,"2

1.2.- De lo anterior resulta entonces que el establecimiento de esta prolija normativa jurídica, tanto sustantiva como orgánica y de procedimiento, debe tener un objeto, que precisamente justifica su existencia. Dicho objeto corresponde a lo que se denomina un BIEN JURIDICO, o sea un interés, en este caso colectivo o social, que se trata de precaver mediante las normas ya referidas. Pues bien, de la sola lectura de los artículos $1^{\circ}, 2^{\circ}$ y $6^{\circ}$ del D.L. 211, entre otros, es manifiesto que dicho bien jurídico es la libre competencia, entendida como el conjunto de las condiciones jurídicas y económicas que deben cumplirse para que los agentes económicos (incluyendo al Estado en algunos casos) desarrollen sus actividades económicas lealmente y en un pie de igualdad básica.

Se desprende así entonces, como consecuencia natural de lo señalado, que las facultades que el D.L. 211 concede a los órganos de defensa de libre competencia para prevenir, investigar, corregir y reprimir los atentados a la libre competencia (artículo $6^{\circ}$ ), en cuanto ellos importan una intervención del Estado en actividades de particulares, deben entenderse circunscritas y limitadas por el bien jurídico que se trata de defender. Lo dicho, tratándose de las facultades represivas que la Ley otorga a estos órganos, se traduce en la práctica en que sólo podrán reprimirse aquellos actos o hechos que objetivamente lesionen o pongan en peligro el bien jurídico, que es la libre competencia y que estén descritos como delito en el D.L. 211. Es el daño al bien jurídico o su objetiva puesta en peligro la que justifica la intervención punitiva o represiva de los órganos de defensa de la libre competencia.

\footnotetext{
2 Comisión Resolutiva D.J. 211: Resolución N³68, de 07 de abril de 1992.
} 


\section{2.- La Infracción al bien jurídico protegido por el D.L. 211; naturaleza jurídica y sus efectos.}

2.1.- Según se adelantó en el párrafo anterior, y a diferencia de lo que han sostenido los órganos antimonopolios en Chile, en nuestro entender quedan definitivamente fuera del ámbito de represión y castigo del D.L. 211 aquellos actos que consistan en una simple intención de perturbar, restringir o impedir la libre competencia, cuando dicha intención no conlleva una efectiva lesión o puesta en peligro del bien jurídico protegido por la ley. Este principio, que es universalmente reconocido en el ámbito del derecho penal (las meras intenciones no son punibles), es también válido y vigente respecto de la represión o castigo por vía administrativa de determinadas conductas en relación a la libre competencia. La mera intención de impedir o restringir la libre competencia, si no lesiona o pone en peligro el bien jurídico, no puede ser objeto de medidas coercitivas que afecten la libertad de los particulares; máxime si entre estas medidas coercitivas hay algunas claramente punitivas, como lo son la aplicación de multas o la disolución de personas jurídicas, y otras que sin revestir muy claramente el carácter de una pena, también importan una intromisión en la esfera de los derechos individuales de los agentes económicos (principalmente su libertad) ${ }^{4}$.

Sobre este aspecto y consistente con lo expuesto (en particular en lo que concierne a la naturaleza jurídica de la infracción prevista y sancionada en el D.L. 211), la Excma. Corte Suprema de Justicia ha señalado en un importante fallo de unanimidad:

“... $8^{\circ}$ ) Que apreciando los antecedentes del modo que la ley dispone, se advierte que la empresa requirente es extranjera, no siendo conocida en nuestro país, por lo que resulta aventurado asegurar que la inscripción por parte de la sociedad... de marcas comerciales que se encuentran registradas y que son usadas por la empresa..., para distinguir sus establecimientos de supermercados e hipermercados en diversos países del mundo, ha tenido por objeto entorpecer el ingreso o tratar de impedir el mismo al mercado nacional en el rubro de supermercados, estableciendo barreras para dicho ingreso y que, para ello, hubiere existido concierto entre las dos sociedades requeridas. Lo anterior, en razón de que para poder llegar a una conclusión clara y contundente sobre dicha materia, debe haber pruebas de igual naturaleza, las que en el presente caso no existen. Sólo se podría arribar a tal conclusión, mediante simples conjeturas, lo que, dada la trascendencia del problema, no resulta prudente en el presente caso;

"Que, en efecto, la normativa que regula el asunto que ocupa a esta Corte, ha dado el carácter de un verdadero delito a la infracción que se ha imputado a la

\footnotetext{
${ }^{3}$ Vid. Infra, punto $111,2-, 2.1-$

Son medidas de esta clase, por ejemplo, la peohibición de celcbrar un determinado contrato o realizar un acto: o cl obligat al agente a dejarlo sin efecto, y aùn el hecho de representar a un agente la ilegitimidad de un acto realizado.
} 
recurrida, el que, por aplicación del principio general establecido en el artículo 39 del Código de Procedimiento Penal, no puede ser perseguido respecto de las sociedades recurridas, por lo que se les ha impuesto la sanción de multa, pues así lo permite expresamente el artículo 17 del D.L. 211, en lo que podría estimarse una excepción al principio anteriormente mencionado.

Por lo tanto, para poder imponer esta sanción, el tribunal debe adquirir la plena convicción de que los hechos reclamados constituyen la infracción que se ha imputado y que ella ha tenido la finalidad que se le asigna. Para ello, la ley ha dispuesto que se debe fallar en conciencia. Y, haciéndolo de este modo, esta Corte no ha llegado a la convicción de que las conductas antes descritas, de inscripción de las marcas de que se trata, hayan perseguido el fin de entrabar el ingreso al mercado nacional de la empresa... y, de consiguiente, que ello importe una infracción al artículo $2^{\circ}$ letra f) del Decreto Ley tantas veces citado;

“ $\left.9^{\circ}\right)$ Que, por lo anterior, los recursos deducidos deben entonces prosperar;

"... De conformidad con lo anteriormente expuesto y normas legales que se han mencionado, se declara que se acogen los recursos especiales deducidos..., resolviéndose que los actos objeto del proceso no constituyen la infracción que se les ha imputado y que se rechaza el requerimiento del Sr. Fiscal Nacional Económico y que, por lo tanto, las multas impuestas por Resolución $\mathrm{N}^{\circ} 543$ de la H. Comisión Resolutiva, de fecha nueve del mes de junio del año en curso, escrita a fs. 664 , quedan $\sin$ efecto." ${ }^{5}$

2.2.- De lo expuesto se concluye entonces que para reprimir, sancionar y aún representar como ilegítimo un acto (en el sentido de contrario al D.L. 211), es menester que objetivamente exista una situación de obstáculo a la libre competencia, actual o inminente, que es lo que se trata de sancionar o precaver. El acto o hecho que se reprime necesariamente ha de lesionar o poner en peligro la libre competencia, es decir, debe ser idóneo para producir ese efecto, y en términos objetivos debe producirlo. Un acto que no reúne estas condiciones nunca podrá ser ilegítimo a la luz de las normas del D.L. 211 pues, en todo caso, tanto la existencia objetiva de la infracción cuanto la culpabilidad del imputado deben encontrarse plenamente acreditadas, en base a antecedentes precisos, concretos y graves, debidamente ponderados del modo que establece la ley. No basta, en síntesis, la simple sospecha o conjetura de que tal o cual conducta podrá ser acaso atentatoria contra la libre competencia, si tal convicción no está afincada en una prueba "clara y contundente". No basta, en fin, sancionar en base a un mero peligro de infracción ni resulta legítimo imponer sanción cuando estamos en presencia de una mera manifestación de intenciones (como ocurriría, v. gr., con el anuncio de ejercer las acciones judiciales preventivas y/o sancionatorias que la Ley $N^{\circ} 19.039$ confiere al titular de una marca comercial), lo que de conformidad a nuestra legislación no

\footnotetext{
Corte Suprema, 30 de noviembre de 1999. Recurso especial artículo 19 D.1.211, Rol N²231-99.
} 
puede ser objeto de reproche a menos que alguna disposición legal así lo exprese (como sucede en el caso de la proposición o conspiración en materia penal). En otros términos, la sola manifestación de voluntad contraria a la norma puede llevar incluso al castigo de la tentativa inidónea y absurda (v. gr. tratar de matar a otros con supercherías), lo que ha llevado a que en el Estado de Derecho moderno el fundamento del castigo sea el disvalor de acción, y siempre y cuando tal acción disvaliosa lesione efectivamente o al menos ponga en peligro el bien jurídico protegido. Lo demás quedará necesariamente en el ámbito de las meras intenciones, que no son censurables.

En consecuencia, y considerando que las decisiones de los órganos de la Libre Competencia deben ceñirse estrictamente al principio de legalidad, toda medida punitiva que éstos impongan deberá derivarse, a lo menos, de una objetiva y concreta puesta en peligro del bien jurídico protegido. Es en este éntendido, en fin, que deben interpretarse las palabras del D.L. 211 cuando, en sus artículos $1^{\circ} \mathrm{y}$ $2^{\circ}$, sanciona incluso aquellos actos "que tiendan a impedir la libre competencia."

\section{III.- LIBRE COMPETENCIA Y MARCAS COMERCIALES EN LA NORMATIVA NACIONAL.}

\section{1.- Las marcas comerciales en la Ley $\mathrm{N}^{\circ} 19.039$; Monopolio legal.}

1.1.- Mucho se ha escrito acerca de la especial naturaleza jurídica de la denominada "propiedad industrial", del derecho de dominio que sobre ella recae y de la trascendente finalidad de fomento y protección que se persigue con la misma. No es entonces nuestro interés el insistir en temas ya tratados. Sín embargo, y a modo de prolegómeno del análisis que iniciamos, resulta de interés el traer a colación las palabras del profesor Claro Solar en cuanto a la utilidad y al fin de las marcas comerciales. Dice en esta parte el autor:

"La utilidad de la marca se manifiesta así por su mismo fin. Sirviendo para revelar la procedencia del producto, no es menos útil al consumidor que al fabricante o comerciante: al primero le permite reconocer el producto que ha merecido su confianza y que desea continuar empleando; a los otros les da el medio de retener su clientela, estableciendo la reputación de la casa de comercio que sur inistra los artículos con esa marca que los clientes conocen. Es la marca, dice Pouillet, la que da a la mercadería su ndividualidad; ella permite reconocerla entre mil otras análogas o semejantes. Mientras más apreciada es la mercaderia, mayor precio tiene la marca. Ella llega a ser, en ocasiones, una propiedad considerable.

"Se puede dar el nombre de marca, por consiguiente, a todo signo que sirva para distinguir los productos de una industria o los objetos de un comercio. La marca de fábrica garantiza el origen del producto que la lleva; la marca de comercio, 
la explotación. La marca ampara el trabajo del que la usa; pero el consumidor viene a ser también indirectamente protegido, tanto contra el fraude que usurpa la reputación del industrial que crea el producto como contra el producto que desnaturaliza los objetos entregados en buen estado por el fabricante.",

Precisando luego respecto del marco de protección legal en que se inserta la marca comercial debidamente constituida, el mismo autor señala:

"La marca tiene por objeto dar a los fabricantes o a los comerciantes una protección efectiva contra los concurrentes que trataran de aprovecharse de la notoriedad adquirida por otros, creando una confusión en el espíritu del público y engañándolo con respecto a la procedencia de los artículos que se le ofrecen. Estos rivales inescrupulosos, apropiándose así de la reputación adquirida por ciertos productos como resultado de la probidad comercial y de los perseverantes esfuerzos del que los vende o fabrica, recogerían el fruto de trabajos en que no han tomado participación alguna y de una reputación que nada han hecho ellos por adquirir. $Y$ en esto no sólo serían dañados fabricantes o comerciantes, sino el público mismo. La marca impide esta concurrencia indebida y permite atribuir a cada uno lo que le es debido, procurándole un medio eficaz de conservar la clientela que ha logrado formarse. Para alcanzar este fin es necesario que toda posibilidad de confusión sea eliminada; y basta para ello que el comerciante o fabricante tenga la exclusividad del uso de su marca para los productos de su comercio e industrias similares, y en esto consiste precisamente la propiedad de la marca."

1.2.- De lo dicho en el numeral precedente derivamos entonces, necesariamente, a un aspecto de la mayor relevancia. La marca comercial, cuyo origen remoto lo encontramos en los llamados "privilegios" concedidos por el soberano a partir de la segunda mitad del siglo $\mathrm{XV}^{8}$, confiere a su titular un derecho exclusivo de utilización y aplicación, incluyendo el derecho a oponerse a su uso por parte de terceros ajenos a la marca. Precisamente, exclusivo significa "único, solo, excluyendo a cualquier otro, que excluye o tiene fuerza y virtud para excluir", particularidad ésta que, extrapolada al ámbito de la legislación marcaria, necesariamente sugiere la existencia de lo que en doctrina se denomina "monopolio legal" y que, a su turno, nos lleva a la idea de un hacer, unido a la ineludible condición de que otros no hagan lo mismo a menos que exista una expresa autorización o licencia del titular para el "ius utendi". La esencia del derecho de

\footnotetext{
${ }^{6}$ Cl.ARO SOLAR, Luis: Explicaciontes de Derecba Ciril Chileno y Comparado, Tomo VI, Editorial Juridica de Chile, Santiago, 1992, pp. 620 y 621 .

7 CLARO SOLAR; op. cit., pp. 625 y 626.

8 VOYAME, Joseph: "La Propriété Indusirielle"; Berna, 1966, p. 5.

9) Diecionario de la Lengua Española de la Real Academia de la Lengua, Vigésima Edición, Editorial Espasa Calpe.
} 
patentes no reside tanto en poder hacer una cosa, sino en impedir que otros hagan la misma $\cos ^{10}$.

Más aún, en materia de propiedad industrial la existencia de este monopolio tiene un reconocimiento directo en la Constitución Política de la República de 1980 bajo la forma de un derecho constitucional (artículo $19 \mathrm{~N}^{\circ} 25$ ), al igual que lo encuentra en la ley (concretamente en el artículo $5^{\circ}$ del D.L. 211 y artículos 33, 34 y 38 del D.S. $N^{\circ} 177$ del Ministerio de Economía -Reglamento de la Ley No 19.039 sobre Propiedad Industrial-):

- El artículo $19 \mathrm{~N}^{\circ} 25$ de la Constitución Política garantiza el derecho de propiedad industrial sobre las marcas comerciales. Por expresa disposición Constitucional, a este derecho le son aplicables las garantías que a propósito del derecho de propiedad otorga el artículo $19 \mathrm{~N}^{\circ} 24$ de la Constitución Política en sus incisos segundo, tercero, cuarto y quinto.

- El artículo $5^{\circ}$ del D.L. 211 reconoce la vigencia de las normas sobre propiedad industrial y el monopolio legal que ellas consagran, al establecer expresamente que, sin perjuicio de lo establecido en las normas sobre defensa de la libre competencia, continuarán vigentes, entre otras, las disposiciones legales y reglamentarias relativas a la propiedad industrial e intelectual ${ }^{11}$. Asi, entre las normas cuya vigencia reconoce expresamente el artículo $5^{\circ}$ citado se encuentran las que constituyen el actual Reglamento de la Ley $\mathrm{N}^{\circ} 19.039$, que debe entenderse incorporado a esa Ley. Pueden mencionarse, entre otras, las siguientes disposiciones del referido Reglamento:

- Artículo 33: "La marca comercial confiere a su titular el derecho exclusivo de utilizarla en la forma que se le ha conferido y para los productos, servicios, establecimientos comerciales o industriales comprendidos en el privilegio".

- Artículo 86: "El titular de un privilegio industrial goza de un derecho exclusivo y excluyente para utilizar, comercializar, ceder o transferir a cualquier título, el objeto de la protección y el derecho que se le ha conferido".

- Artículo 88: "La marca comercial confiere a su titular el derecho exclusivo a utilizarla y aplicarla para la distinción de los productos, servicios, establecimientos comerciales o industriales para los cuales ha sido conferida, con facultad para:

a) Oponerse al uso o aplicación de la marca realizado por terceros, o una que sea similar y que pueda inducir a error o confusión en el público en relación con los productos o servicios en cuyas clases se encuentra registrada.

\footnotetext{
${ }^{10}$ GARRIGUís, Joaquin: "Temas de Derecho Vivo"; "La propicdad Industrial y la Empresa". Madrid, 1978, p. 215.

11 A la fecha de dictación del D.L. 211, la legislación vigente en materia de marcas comerciales era el D.I. N ${ }^{\circ}$ 958, hoy derogado por la Lev $\mathrm{N}^{\circ} 19.039$ que lo reemplazó y sucedió.
} 
b) Impedir el uso o aplicación de una marca o cualquier otro signo que pueda causar un perjuicio al titular de un privilegio o cuando disminuya el valor distintivo o comercial de la marca".

En fin, tan amplia e incondicional es la protección que la Ley otorga a estos privilegios que el artículo 34 del Reglamento señala: "La utilización de la marca no será condición para su registro, vigencia o renovación".

1.3.- En síntesis, las normas constitucionales y legales referidas definen el más amplio rango de protección a la propiedad industrial. El derecho que confiere una marca comercial a su titular es un privilegio, único y exclusivo, en cuya virtud dicho titular tiene la prerrogativa de usar la marca comercial y de excluir a cualquier otro en ese uso. Por eso es que estamos frente a un monopolio legal, en el sentido de que se trata de una institución que la Constitución y la ley exceptúan de las normas sobre libre competencia; concretamente, de las disposiciones del D.L. 211.

Quien ha registrado a su nombre una marca comercial, en la forma que establece la ley y sin oposición ni reclamo alguno de terceros, tiene entonces el derecho de usarla -o no- mientras permanezca vigente. Del mismo modo, el tiajar de la marca tendrá siempre el derecho de oponerse a que cualquier otra persona utilice dicha marca para sus actividades comerciales, pudiendo ejercer en ese evento, ante los tribunales competentes y en resguardo de tales derechos, todas las acciones civiles y criminales que la ley le otorga. Por lo tanto, si las barreras o limitantes impuestas a terceros respecto del uso exclusivo y excluyente de una marca comercial vigente provienen precisamente de la ley, dificilmente puede la misma ley considerar como constitutivo de una infracción punible el sólo ejercicio, por parte del titular de la marca, de los derechos inherentes a la misma. Entenderlo en sentido contrario conlleva, en fin, a dejar sin efecto el monopolio legal sobre la marca y a transformar en letra muerta todo el estatuto de garantías que la Constitución y la ley contemplan en torno a ella, lo que nos parece inaceptable y de suyo riesgoso. Según se dijo más arriba, el artículo 5 del D.L. 211 debió hacer expresa salvedad -en cuanto a su aplicación- respecto de las disposiciones legales y reglamentarias referidas a la propiedad industrial e intelectual; disposiciones que, a no mediar esta expresa declaración, habrían sido derogadas tácitamente por el D.L. 211 en cuanto al monopolio legal que confieren al titular de la marca.

De lo señalado entonces se desprenden, a nuestro entender, las conclusiones siguientes:

a) Que el ser titular de una marca comercial no importa una violación de los preceptos del D.L. 211, los que no pueden aplicarse a situaciones en que es la ley la que confiere un monopolio.

b) Que, por lo tanto, no puede ser un acto contrario a la libre competencia el constituir propiedad industrial sobre una marca comercial, ni el realizar los trámites necesarios para su concesión. 
c) Que tampoco puede ser contrario a las normas del D.L. 211 el sólo hecho de adquirir de un tercero una marca comercial, válidamente constituida.

d) Que el ejercicio por el titular del registro marcario de las facultades y derechos que le concede su privilegio, no puede en caso alguno ser considerado una conducta ilícita, de aquellas contempladas en los artículos $1^{\circ}$ y $2^{\circ}$ del D.L. 211.

e) Que entre esas facultades, está precisamente la de impedir que otro use la marca que se encuentra registrada a nombre del titular.

f) Que lo anterior se efectúa mediante la interposición de las acciones judiciales que la ley sobre propiedad industrial establece y, por lo tanto, dicho ejercicio jamás podrá ser una conducta sancionable por las normas de los mencionados artículos $1^{\circ}$ y $2^{\circ}$ del D.L 211.

g) Finalmente, que mientras se encuentre vigente un registro marcario a nombre de una persona, sólo puede ser utilizado para la misma clase por un tercero si el titular lo autoriza expresamente, o si se declara la nulidad del registro mediante sentencia judicial ejecutoriada dictada por el Tribunal competente. Por lo tanto, las facultades que el D.L. 211 concede a los órganos de control antimonopolios en caso alguno podrán extenderse a la posibilidad de impedir a ese tercero el uso de la marca registrada; mucho menos si existe sub lite un procedimiento judicial en que se discute la validez del registro.

En suma, no es posible pretender la aplicación de las normas del D.L. 211 (artículos $1^{\circ}$ y $2^{\circ}$ especialmente) al hecho de poseer un registro marcario vigente. Tampoco es aplicable a la constitución de propiedad marcaria, ni a la compra de un registro marcario. Menos aún es aplicable al ejercicio de las acciones judiciales que ese privilegio otorga.

\section{2.- Competencia de los organismos antimonopolios ante la normativa sobre marcas comerciales; tesis del abuso del derecho.}

2.1.- Llegamos entonces al aspecto central de que trata el presente trabajo de investigación. Según se adelantó a modo introductorio, reiterados son los casos en que las Comisiones para la defensa de la libre competencia se han arrogado competencia para conocer sobre conflictos de trasfondo netamente marcario. A este respecto, existe ya u: a jurisprudencia sostenida de los antedichos órganos que reconoce y legitima su intervención en asuntos marcarios, cuando en su concepto se ha incurrido en actos de competencia desleal potencialmente idóneos para crear distorsiones y confusión en el mercado, afectando su transparencia. Según esta jurisprudencia, la amplitud casi ilimitada de las normas del D.L. N²11, sumada a la inexistencia de normas de aplicación directa e inmediata que impidan la intervención de las Comisiones en tales materias, legitiman del todo su intervención y pronunciamiento; incluso si tales pronunciamientos implican desconocer de plano 
los derechos que la ley confiere al titular de un registro marcario, considerando incluso reprochable el sólo ejercicio de ellos.

Para un mejor análisis de esta jurisprudencia, la agruparemos en torno a las doctrinas más relevantes que de ellas emanan:

a) Reiteradamente, las Comisiones han considerado como un atentado a la libre competencia el registro en Chile -por terceros- de marcas comerciales de propiedad de empresas extranjeras, si en virtud de tal registro se dificulta -actual o potencialmente- la libre comercialización o el libre ingreso en el mercado interno de los productos, servicios o establecimientos industriales o comerciales reivindicados por la marca, respectivamente. En apoyo de tal intervención y como fundamento de ella, los órganos precitados han recurrido una y otra vez a la tesis del "abuso del derecho", en el sentido de que lo dispuesto por el artículo 5 del D.L. N²11 cuando mantiene vigentes las normas legales y reglamentarias sobre propiedad industrial e intelectual- no impediría a los organismos antimonopolios conocer de aquellas situaciones que pudieran ser contrarias a las normas sobre libre competencia. La protección para el uso de una marca comercial -se argumenta-, en las condiciones que la Ley de Propiedad Intelectual establece, no excluiría la posibilidad de que el titular de la misma abuse de los derechos subsecuentes, creando una situación de hecho actual o potencialmente atentatoria de la libre competencia que justifica la formulación del reproche. Más aun, la H. Comisión Resolutiva ha llegado a declarar que las normas del D.L. N²11 tendrían incluso la fuerza de derogar tácitamente -o al menos hacer inaplicables- las disposiciones legales y reglamentarias sobre propiedad industrial e intelectual, cuando los derechos que ellas consagran se ejercen con abuso actual o potencial. Son reiterados los fallos en tal sentido, cuya doctrina central se resume en los siguientes:

- "De acuerdo con lo dispuesto en el artículo $5^{\circ}$ del D.L. №211, de 1973, que mantiene vigentes las disposiciones legales y reglamentarias referidos a la propiedad intelectual e industrial, no se impide a los organismos antimonopolios conocer de aquellas situaciones que pudieran ser contrarios a las normas sobre libre competencia, por cuanto dicha protección para el uso exclusivo de la marca del invento o del modelo, en las condiciones que la Ley de Propiedad Intelectual establece, no excluye la posibilidad que un abuso en el ejercicio de tal derecho pueda atentar contra la libre competencia, lo que no quedaría amparado por dicha protección." 12

- "En primer término, es necesario tener presente que se ha resuelto por los organismos de defensa de la libre competencia que el artículo $5^{\circ}$ del Decreto Ley $N^{\circ} 211$, de 1973, que mantiene vigentes las normas legales y reglamentarias referentes a la propiedad industrial, no impide a dichos organismos conocer de aquellas situaciones que pudieran ser contrarias a las normas sobre libre

Comisión Resolutiva, Res. $N^{\circ} 316$, de 16 de mayo de 1989 
competencia y que por mandato de la ley están precisamente sometidas a su conocimiento, por cuanto la protección para el uso exclusivo de la marca, del invento o del diseño, en las condiciones que la Ley de Propiedad Industrial establece, no excluye la posibilidad de que un abuso en el ejercicio de ese derecho pueda atentar contra la libre competencia." 13

b) Por otra parte, del conjunto de fallos que se pronuncian sobre esta materia, sustentados todos en la tesis del "abuso del derecho", se observan también algunos en que la $\mathrm{H}$. Comisión Resolutiva prescinde derechamente de toda consideración respecto del elemento de lesión objetiva al bien jurídico protegido, sancionando exclusivamente en base a conceptos tales como "idoneidad", "virtualidad"y "potenicialidad" de infracción. Según estos fallos, en fin, los organismos antimonopolios pueden intervenir y sancionar sin necesidad de que efectivamente se haya producido un impedimento o restricción al bien jurídico protegido (cuestión que consideramos errónea, según se explicó en el capítulo II). En este sentido, han señalado las referidas Comisiones:

- "4 Que esta Comisión estima que la sanción de los hechos, actos o convenciones que, por vía de ejemplo, enumeran las letras a), b), c), d) y e) del citado artículo $2^{\circ}$ del Decreto Ley $N^{\circ} 211$, de 1973 , tiene el propósito de reprimir las conductas que tiendan a impedir, entorpecer o restringir la libre competencia comercial e industrial, sin que esté condicionada, como parece entenderlo la defensa, a que se haya acreditado un impedimento o restricción efectivos de la libre competencia en un determinado mercado, ni que se haya producido un perjuicio efectivo de los consumidores, o se haya obtenido necesariamente una ganancia ilícita por parte de comerciantes o industriales. Los hechos y conductas antes referidos pueden ser sancionados, con prescindencia de que se produzcan o no los efectos que se han mencionado precedentemente, ya que su ilicitud es determinada por la ley por su virtualidad o ido neidad, siendo suficiente para calificarlos como contratios a la libre competencia que dichos hechos o conductas tiendan a eliminarla o restringirla, aun cuando tales efectos no lleguen, en el hecho, a producirse." ${ }^{14}$

c) Asimismo, la II. Comisión Resolutiva ha considerado en ocasiones como irrelevante, al momento de aplicar las normas sobre defensa a la libre competencia, el que una marca comercial se encuentre vigente o que, más aun, su validez plena sea reconocida incluso por los tribunales marcarios competentes, en el seno de un proceso sobre nulidad de la marca. Tal criterio, pues, se ilustra claramente en el fallo siguiente:

\footnotetext{
${ }^{13}$ Comisión Preventiva Central: Dictámenes $\mathrm{N}^{\circ} \mathrm{s} 953,954,974$ y 1017.

Comisión Resolutiva, Res. No67, de 31 de octubre de 1979. Esta tesis, según se señaló en cl Capítulo II, ha sido rechazada por la (cores Suprenia (ier nota $\mathrm{N}^{\circ} 4$ ).
} 
- "4. Que esta Comisión, apreciando la prueba en conciencia comparte la opinión del señor Fiscal Nacional, ya que si bien la denunciada estaba autorizada a entablar las acciones que dedujo, éstas, en su conjunto, y atendida su finalidad, adquieren una connotación de ilicitud, porque, a juicio de esta Comisión, tuvieron como único objetivo, impedir o, al menor, restringir la competencia que significaba la comercialización de fósforos chinos..." " 6 ". Que en mérito de lo expuesto, no reviste gran importancia el resultado de la controversia suscitada a raíz de estas inscripciones, las cuales, a mayor abundamiento, no fueron respaldadas en forma unánime por los organismos competentes, ya que hubo algunas opiniones que las estimaron nulas y otras, en cambio, válidas. Aunque en definitiva se les considere válidas, tal validez no desvirtúa la finalidad que tuvo la conducta denunciada de entorpecer la libre competencia, objetivo que logró, porque efectivamente la entorpeció con resultados irreversibles, desde el momento en que... debió comercializar un producto importado, que ha sido vendido en el mercado, con otra marca y etiqueta, de modo que carece de mayor relevancia, para la comercialización ya hecha, lo que resuelvan, en definitiva, los organismos competentes, porque tal resolución sólo regitá para el futuro." 15

Sin embargo, y según hemos señalado también en el segundo acápite de este trabajo, consideramos que el criterio arriba apuntado no encuentra sustento en un Estado de Derecho y, más aun, constituye irremediablemente un cultivo de incertidumbre juridica $y$ una fuente inagotable de contradicciones entre lo que resuelvan sobre la misma materia los tribunales de la Ley $\mathrm{N}^{\circ} 19.039$-por un lado- y los órganos antimonopolios -por el otro-. Asimismo, el fallo precitado no deja de llamar la atención por cuanto, a fin de cuentas, lo que hace es condicionar o supeditar el pleno ejercicio de los derechos y facultades que concede la legislación marcaria a un hecho que la misma normativa por cierto no consulta: que la validez y vigencia de la marca comercial sea reconocida y expresamente declarada por los tribunales establecidos en la Ley $\mathrm{N}^{\circ}$ 19.039. Según la H. Comisión Resolutiva, pues, las normas del D.L. 211 podrán aplicarse con total prescindencia de lo que señala la legislación industrial e intelectual (llegando incluso a desconocer del todo los derechos que de ella emanan), en tanto los tribunales competentes no declaren la validez de la marca por la vía de rechazar la demanda de nulidad respectiva, por sentencia firme y ejecutoriada. Mientras ello no ocurra, pues, todo titular de una marca comercial estará sujeto a la eventual intervención y sanción por parte de los organismos antimonopolios, por el sólo hecho de ejercer -o incluso anunciar- las acciones que la Ley $N^{\circ} 19.039$ contempla en resguardo de la exclusividad que confiere la marca. Hasta ese momento, dice el fallo citado, la conducta del titular de la marca inicialmente impugnada puede ser constitutiva de infracción al D.L. N²11 y sujeta a reproche; pero después de él -y automáticamente- dejará de tener tal

Comisión Resolutivis, Res. N¹69, de 28 de marzo de 1984 , 
carácter (pues el fallo rige "para el futuro"), no obstante las sanciones ya impuestas y el perjucio efectivamente causado a ese titular. Tal criterio, en sintesis, no encuentra sustento dogmático alguno y, más aun, guarda en si mismo un sesgo de arbitrariedad e incertidumbre juridica que necesariamente debe ser superado.

d) En sintesis, y como corolario de la tesis sustentada por las Comisiones Antimonopolios, arriba descrita, la efectiva aplicación y vigencia de la normativa constitucional, legal y reglamentaria sobre propiedad industrial, en sus aspectos orgánicos, procesales y de fondo, queda entonces supeditada, más que al contenido de sus propias disposiciones y al cumplimiento de ellas por el titular de la marca, a la sanción o aquiescencia activa o pasiva de los órganos de defensa de la libre competencia; activa en caso de intervenir positivamente en una situación determinada, rechazando el requerimiento del Fiscal Nacional Económico o la denuncia particular, según corresponda, y pasiva en tanto tal intervención no se produce, permaneciendo en estado "latente". Tales organismos, pues, estarían facultados para desconocer en cualquier momento los derechos que aquella confiere al titular de la marca, sin más requisito que la concurrencia de antecedentes considerados -por los mismos órganos-como virtualmente aptos o idóneos para configurar la infracción a la libre competencia. En otros términos, el registro marcario tendrá el valor y producirá los efectos que le asigna la ley de propiedad industrial sólo hasta cuando los órganos antimonopolios no digan lo contrario; y ello con total prescindencia de la efectiva lesión o puesta en peligro del bien jurídico protegido, o del cumplimiento de los requisitos y prescripciones de la mencionada ley.

Los efectos aquí descritos están reflejados en decisiones como las que pasamos a referir:

- "4.4... En consecuencia, no obstante que el referido registro no constituye por sí solo una conducta reprochable desde el punto de vista de las normas sobre libre competencia -ya que pudo haber tenido por objeto proteger la marca en la época en que... tenía la distribución de esos productos-, esta firma no puede impedir que... o cualquier otra empresa interesada, pueda comercializar dichos productos en Chile, ya que ello constituiría un atentado a la libre competencia, según la letra f) del artículo $2^{\circ}$ del Decreto Ley $\mathrm{N}^{\circ} 211$, de 1973.

" 4.5. En virtud de lo antes expuesto y de acuerdo con lo resuelto reiteradamente por esta Comisión en situaciones similares, el registro de la marca... a nombre de..., a que se ha hecho referencia, no impide la libre importación y/o comercialización en el país, por la firma alemana... o por cualquier otra empresa que aquella designe para tales efectos, de los productos marca..., provenientes de su legitimo productor, la firma alemana ya mencionada, marca que fue puesta en 
dichos productos por su fabricante y que, además, forma parte de su razón social." 16

-"6.4. En virtud de lo antes expuesto y de acuerdo con lo resuelto reiteradamente por esta Comisión Preventiva en situaciones similares, la conducta de..., consistente en el registro, a su nombre, de la marca... y el posterior envío de una carta a la denunciante conminándola a abstenerse de seguir comercializando los productos de esa marca, bajo amenaza de entablar acciones judiciales en su contra, sólo pudo haber tenido por objeto impedir la libre importación y comercialización en Chile, por parte de aquella, de productos importados, legítimos, cuya venta se efectúa con su misma marca de origen, puesta en dichos productos por su fabricante y que, además, está formada por las iniciales de la razón social de éste, lo que constituye un atentado a la libre competencia, según lo dispuesto en la letra $\mathrm{f}$ ) del artículo $2^{\circ}$ del Decreto Ley $N^{\circ} 211$, de 1973 , conducta a la cual... debe poner término de inmediato, bajo apercibimiento de solicitar al señor Fiscal Nacional Económico que formule requerimiento en su contra ante la $\mathrm{H}$. Comisión Resolutiva, para la aplicación de las sanciones que corresponden."

Este fallo, amén de reflejar lo señalado más arriba, muestra también el serio conflicto normativo que subyace en la interpretación amplia ${ }^{18}$ y casi ilimitada de las normas del D.L. $\mathrm{N}^{\circ} 211$, como asimismo el riesgo cierto que involucra la aplicación a ultranza de la tesis del "abuso del derecho", que se presenta muchas veces como aventurada $\mathrm{o}$, a lo menos, poco prudente. Lo anterior, pues, por cuanto a pretexto de una amenaza potencial de atentado a la libre competencia, sustentada sobre la base feble del mero anuncio de ejercer las acciones judiciales que la ley expresamente le confiere al titular de la marca registrada en Chile, se formula a su respecto otra amenaza tanto más seria que la anterior para el caso en que insista en dicho ejercicio (no obstante la vigencia del registro pertinente). Semejante determinación o advertencia, por justificada que parezca en el caso dado, puede semejarse incluso a una suerte de acto expropiatorio e irregular del dominio que se tiene sobre el bien inmaterial que constituye la marca, lo que incluso lleva a representarse la posibilidad de que el verdadero origen del abuso del derecho no se encuentre ya en el titular de la marca, sino en quien impide ejercer los derechos inherentes a ella en base a consideraciones que resultan, según se dijo, insuficientes a la luz de la naturaleza jurídica de la sanción punitiva cuya imposición se anuncia.

Expresión de esta interpretación la constituye la Resolución N ${ }^{\circ} 368$ de la H. Comisión Resolutiva, en la que se señala: "Octavo: Que siendo múltiples las formas como se puede llegar a infringir y burlar esta finalidad, el legislador del Decreto Ley 211 debió contemplar disposiciones muy amolias para comprender todas las situaciones que puedan darse y conferir, a la vez, vastas atribuciones a los organismos antimonopolios que establece, destinados a prevenir, corregir $e$ incluso sancionar los hechos o actos que tiendan a impedir, restringir o entorpecer la libre competencia."
} 
- "A juicio de esta Comisión, la época en que se efectuaron los diversos registros y solicitudes de registros de las marcas, por parte de..., por cuenta de..., no es lo relevante en este caso. Lo importante es que cuando... hizo pública su intención de ingresar al mercado nacional, las referidas empresas manifestaron ante los medios de prensa su oposición a que lo haga utilizando el nombre..., haciendo valer los dos registros actualmente vigentes a nombre de... sobre la marca, y respecto de los cuales se están tramitando sendos juicios de nulidad en los tribunales marcarios; posición que se ha mantenido hasta la fecha". ${ }^{19}$

En este caso, al igual que en los anteriores, lo que se reprocha es la manifestación ex-ante hecha por el titular de la marca, en orden a ejercer las acciones que la Ley $N^{\circ} 19.039$ le confiere. Con ello, se entorpece severamente incluso el derecho consagrado en el artículo $19 \mathrm{~N}^{\circ} 3$ de la Constitución Política, por la vía de una declaración de los órganos de defensa de la libre competencia destinada a inhibir el futuro ejercicio de las acciones civiles y criminales que corresponden a aquel a cuyo nombre está inscrita la marca comercial. Ello es jurídicamente inadmisible, pues esas acciones judiciales emanan de la naturaleza misma del registro marcario, y son los tribunales competentes para conocer de ellas los que deben resolver si son o no procedentes.

Existen en nuestro sistema jurídico los denominados "derechos absolutos", es decir, aquellos cuyo ejercicio no está sujeto a restricciones ni pueden de antemano ser impedidos o vedados. El caso característico es el "Derecho a la Acción Judicial", es decir, el derecho de recurrir a los tribunales de justicia reclamando su intervención legal, en negocios de su competencia.

Esto significa, pues, que cualquier persona -salvo las excepciones legales expresas- tiene derecho a ejercer las acciones judiciales que estime convenientes en defensa de sus intereses, y ningún órgano o decisión puede impedirlo en forma anticipada. Lo contrario significaría una denegación de justicia y un serio agravio al Estado de Derecho. Al respecto, numerosas son las disposiciones legales que confirman lo señalado:

a) Artículo $19 \mathrm{~N}^{\circ} 3$ inciso $3^{\circ}$ de la Constitución Política:

...'Toda persona tiene derecho a defensa jurídica en la forma que la ley señale y ninguna autoridad o individuo podrá impedir, restringir o perturbar la debida intervención del letrado si hubiere sido requerida..."

Por lógica consecuencia entonces, toda persona tiene derecho a requerir de los tribunales de justicia su intervención, y una vez hecho el requerimiento, nadie puede restringir, perturbar ni impedir tal intervención. No reconocer esta consecuencia necesaria significaria desconocer todo sentido a la garantía constitucional en cuestión.

Comisión Preventiva Central; Informe de fecha 07 de agosto de 1998, en Recurso de Reclamación contra Dictámenes $N^{\circ} \mathrm{s} 1040$ y 1041 
b) Artículo 73 inciso $2^{\circ}$ de la Constitución Política y artículo 10 inciso $2^{\circ}$ del Código Orgánico de Tribunales, que reconocen el principio de inexcusabilidad de los tribunales. De nada sirve esta garantía si sus destinatarios no tienen a su vez el derecho irrestricto y absoluto de reclamar a los tribunales de justicia su intervención legal.

c) El artículo 10 del Código de Procedimiento Penal concede acción penal pública para impetrar la averiguación de todo hecho punible y sancionar, en su caso, el delito que resulte probado. El artículo 11 del mismo Código dispone que la acción penal pública es la que se ejercita a nombre de la sociedad para obtener el castigo de todo delito que deba perseguirse de oficio. En fin, el artículo 15 señala: ..." La acción penal pública puede ser ejercida por toda persona capaz de parecer en juicio, siempre que no tenga especial probibición de la ley y que se trate de delitos que deban perseguirse de oficio"... Asimismo, según el artículo 83 del Código citado "todo el que tenga conocimiento de un becho punible puede denunciarlo...". Por su parte, el artículo 93 del mismo cuerpo legal dispone que "toda persona capaz de parecer en juicio por si misma, puede querellarse ejercitando la acción pública de que se trata en los articulos 10 y 11 de este Código, si no le está expresamente probibido por la ley...'. Sobre las mismas materias tratan por su parte los artículos 53 y 111 y siguientes del Código Procesal Penal.

En síntesis, resulta inconveniente e improcedente, desde todo punto de vista, un pronunciamiento a priori de los órganos defensa de la libre competencia respecto de la legitimidad o ilegitimidad de las marcas comerciales y, por lo tanto, sobre la legitimidad o ilegitimidad del ejercicio de las acciones judiciales que emanan de la marca comercial. Tal pronunciamiento implica, por lo demás, un prejuzgamiento de materias que son específicas del registro, cuyo conocimiento y resolución está entregado por la ley al tribunal marcario respectivo. Necesariamente, pues, tal decisión presupone que los órganos antimonopolios den por sentado -muchas veces sin los antecedentes suficientes, dado el objeto específico que se investiga- que la marca comercial respectiva es efectivamente de propiedad de la empresa extranjera denunciante, y que ella ha sido indebidamente registrada en Chile; pero ello, como es inconcuso, es materia de la que debe conocer exclusivamente el tribunal que la Ley $\mathrm{N}^{\circ} 19.039$ señala, en el marco del respectivo juicio de nulidad. Asimismo, y como consecuencia de lo anterior, las Comisiones deben presuponer también que, siendo ilegítimo -en su concepto- el registro en Chile, existiría en el titular del mismo un ánimo de apropiarse indebidamente de la marca; y ello con el fin preciso de impedir el ingreso de productos o empresas extranjeras. Sin embargo, tal apreciación puede resultar aun más aventurada que la anterior; máxime si la marca se mantiene vigente, o si la demanda de nulidad respectiva es rechazada luego por el tribunal antedicho.

2.2.- La tesis del "abuso del derecho", como premisa de justificación en el actuar de los organismos antimonopolios frente a la normativa sobre propiedad industrial e intelectual, resulta en muchos casos insuficiente e imprecisa; más aun, con ella se 
ingresa derechamente a un laberinto de difícil retorno en cuanto a la certeza, vigencia y real aplicación de los derechos establecidos en la Ley $\mathrm{N}^{\circ} 19.039$, que al fin de cuentas resultan preteridos en base a conductas que muchas veces ni siquiera se han producido, pero que en concepto de los organismos referidos son el germen $O$, en fin, tienen "el potencial" de entrabar o impedir en el futuro la libre competencia.

En consecuencia, el criterio del abuso del derecho sustentado en los dictámenes y resoluciones citadas conlleva, a nuestro entender, a consecuencias negativas y peligrosas, poniéndose en riesgo la seguridad del tráfico jurídico. Como ya señalamos, la protección que la Constitución y leyes referidas otorgan al derecho de propiedad industrial tiene un amplio rango, de modo tal que el concepto de "abuso del derecho" o bien no tiene cabida, o debe entenderse en un contexto muy estricto y limitado, o sea, entendido y aplicado sólo dentro de su ámbito lógico: el de las marcas o propiedad industrial. Ello, por cuanto es la propia ley sobre propiedad industrial la que establece los mecanismos destinados a corregir situaciones como las que plantean las Comisiones en los fallos indicados, recogiendo además la opinión del Sr. Fiscal Nacional Económico. Así por ejemplo:

A) La ley No 19.039, en su artículo 20 letra g) y en relación con los artículos 6 y 6 bis del Convenio de París, prohíbe registrar como marcas comerciales:

- "g) Las marcas iguales o que gráfica o fonéticamente se asemejen, en forma de confundirse con otras registradas en el extranjero para los mismos productos, servicios o establecimientos comerciales $\mathrm{y} / \mathrm{o}$ industriales, siempre que ellas gocen de fama y notoriedad".

B) Además, la misma disposición citada prohíbe también, en su letra j), el registro de:

-" j) Las contrarias al orden público, a la moral y a las buenas costumbres, comprendidas en éstas los principios de competencia leal y ética mercantil."

Según esta expresa disposición, tampoco resultaria atendible el criterio sostenido por las Comisiones Antimonopolios cuando defienden su plena competencia para conocer y resolver sobre materias netamente marcarias. Así por ejemplo, han resuelto estos organismos:

- "Las alegaciones sobre incompetencia de la Comisión Preventiva Central para conocer de la denuncia deben descartarse, porque la competencia desleal cae de lleno en el ámbito de las atribuciones de los Organismos Antimonopolios creados por la ley chilena."20

Sin embargo, los principios de especialidad y radicación parecen señalar lo contrario. Si la competencia desleal se produce con ocasión de un conflicto marcario, en donde dos o más personas se arrogan titularidad o, a lo menos, un mejor derecho sobre la marca, serán entonces los tribunales marcarios los llamados

${ }^{20)}$ Comision Preventiva Central; Dictamen N 891, de 14 de enero de 1994. 
a conocer y resolver tales conflictos. Así se desprende del mandato amplio del artículo 17 inciso $1^{\circ}$ de la Ley $\mathrm{N}^{\circ} 19.039$, cuando señala:

- "Los juicios de oposición, los de nulidad de registro o de transferencias, así como cualquier reclamación relativa a su validez y efectos, o a los derechos de propiedad industrial en general, se sustanciarán ante el Jefe del Departamento de Propiedad Industrial, ajustándose a las formalidades que se establecen en esta ley y a las que disponga el reglamento."

Por lo demás, han sido las propias Comisiones las que, en ocasiones, han declarado expresamente su incompetencia absoluta para conocer de asuntos marcarios:

- “...si bien situaciones como las de la especie podrían eventualmente calificarse como de competencia desleal, previa detenida consideración de su idoneidad para alterar la libre competencia, pudiendo en dicho caso reprimirse o corregirse con arreglo al Decreto Ley 211, del año 1973, la existencia de normas de aplicación directa e inmediata como las transcritas precedentemente, y de organismos jurisdiccionales encargados de aplicarlas, inhiben a los organismos antimonopolios de pronunciarse sobre ellas...,21

C) Del mismo modo, el artículo 22 de la Ley $\mathrm{N}^{\circ} 19.039$ establece un mecanismo de control preventivo en la tramitación de toda solicitud de marcas, de manera de precaver anticipadamente la obtención de registros que se encuentran en los caso de artículo 20 de la misma ley:

- "Antes que el Conservador de Marcas acepte a tramitación una solicitud de marca, el departamento deberá practicar una búsqueda o examen preventivo, a fin de establecer si concurre alguna de las causales de irregistrabilidad señaladas en el señaladas en el artículo 20 ".

Por lo tanto, al admitirse a tramitación una solicitud de marca comercial concurre una verdadera presunción de que no se encuentra en ninguno de los casos indicados en el artículo 20 de la ley, que impiden otorgar el registro.

D) Admitida a tramitación una solicitud de marca comercial, existe un segundo mecanismo de control antes de su otorgamiento: Cualquier interesado puede oponerse al otorgamiento del privilegio si estima que la solicitud respectiva vulnera lo dispuesto en el artículo 20 de la ley No 19.039. Este derecho se consagra y regula en los artículos 71, 72 y 73 del Reglamento de la ley No 19,039.

E) A continuación, existe un tercer control sobre la procedencia de otorgar un registro marcario, que es el momento en que el Departamento de Propiedad Industrial debe resolver sobre la solicitud de registro. Si no ha habido oposición, debe de todos modos verificar si procede o no conceder el privilegio, a la luz de los antecedentes de la solicitud, entre los cuales está precisamente el encontrarse o no

Comisión Preventiva Central; Dictámenes $\mathrm{N}^{\circ} \mathrm{s} 395$, de 11 de octubre de 1983 , y 785 , de 7 de noviembre de 1991 . 
en los casos del artículo 20 de la ley No 19.039. Si ha habido oposición, la autoridad de marcas debe pronunciarse sobre ella, acogiéndola u otorgando el registro.

F) Más aún, concedido el registro marcario existe todavía la acción de nulidad del mismo, cuando se ha concedido con infracción de lo dispuesto en el artículo 20 ya citado. Así lo señala el artículo 26:

- "Procede la declaración de nulidad del registro de marcas comerciales cuando se ha infringido alguna de las prohibiciones establecidas en el artículo 20 de esta ley."

La acción de nulidad prescribe en el plazo de 5 años, contados desde la fecha del registro (artículo 27 de la ley) y puede intentarla cualquier interesado (artículo 77 del Reglamento). El procedimiento a que tales acciones deben sujetarse se encuentran también expresamente regulado en los artículos 77 y siguientes del Reglamento.

G) De lo expuesto entonces se desprenden las siguientes conclusiones:

a.- Que la existencia de estos cuatro mecanismos de control de juridicidad en el otorgamiento de privilegios industriales, hace presumir que al concederse un registro marcario se cumple con los requisitos legales y no se afectan derechos de terceros.

b.- Que las situaciones que los organismos antimonopolios califican como un "abuso del derecho", se encuadran en todo caso dentro de las causales de nulidad del artículo 20 de la ley No 19.039 .

c.- Que los terceros a quienes pueda afectar un privilegio industrial están suficientemente resguardados en sus derechos por los mecanismos que la legislación marcaria establece, tanto mediante el doble control que la autoridad de marcas debe realizar antes de conceder un privilegio, cuanto mediante las acciones de oposición y nulidad que la ley otorga.

d.- Que atendido estos mecanismos de control, el solo hecho de solicitar una marca comercial determinada y obtener el registro de ella no podrá nunca ser un acto que importe el "abuso de un derecho". En definitiva, de lo que se trata es de una expresión del derecho de petición, cuya fuente remota es la Constitución Política de la República (artículo $19 \mathrm{~N}^{\circ} 14$ de la Constitución Política de la República) y, como tal, el ejercicio de este derecho no es abusivo. La autoridad deberá calificar la procedencia o no de la solicitud a la luz de las normas legales vigentes, $y$ frente a ello los particulares podrán oponerse o impetrar las acciones de nulidad en su caso. Es lo mismo que sucede con el derecho a la acción judicial, entendida como el derecho a reclamar de los tribunales de justicia su intervención en materias de su competencia; también es una derivación del derecho constitucional de petición, y los tribunales requeridos deberán calificar la procedencia de la acción deducida. Por eso, nunca será abusivo el ejercicio del derecho a la acción, e incluso en los casos extremos, la misma ley procesal establece 
la responsabilidad por el ejercicio de acciones infundadas (obligación de pagar costas, responsabilidad criminal por el delito de calumnia; etc.)

e.- No puede ser abusivo el ejercicio de un derecho cuando la ley que lo establece y regula señala, clara y precisamente, los mecanismos para decidir sobre la procedencia de la solicitud, otorgándole a los terceros afectados los mecanismos correspondientes para hacer valer sus derechos.

f.- Si no puede ser calificado de abusivo el ejercicio del derecho a solicitar un privilegio industrial, menos aun lo será el hecho de que la autoridad marcaria acoja tal solicitud, pues ello supone que a lo menos en dos oportunidades ha evaluado su procedencia desde el punto de vista de las exigencias legales (artículo 20 de la ley $\mathrm{N}^{\circ}$ 19.039). No puede ser abusivo el otorgamiento del privilegio industrial si los terceros afectados han tenido los mecanismos para hacer valer sus derechos, y no lo han hecho.

g.- En fin, si no puede haber abuso al solicitarse un registro marcario, ni al concederse el privilegio sin oposición de terceros, ni al comprarse por otro la marca comercial concedida, difícilmente puede haber abuso de un derecho cuando el titular del registro marcario vigente ejerce las facultades que son inherentes al dominio sobre él (uso, goce y disposición), ni cuando ejerce los derechos y prerrogativas específicas que la ley señala como propias del privilegio industrial (derecho exclusivo de usar la marca y derecho a excluir a terceros en ese uso). En todo caso, tales situaciones entran de lleno en el ámbito exclusivo de la legislación marcaria (artículo 20 de la ley $\mathrm{N}^{\circ} 19.039$ ) y de los tribunales que ella contempla, los que están llamados a resolver, con amplias facultades, toda clase de conflicto en torno a la validez, efectos, o a los derechos de propiedad industrial en general.

2.3.- En síntesis, la tesis del "abuso del derecho" sienta un negativo precedente en todo el sistema que la Constitución y las leyes han establecido para proteger la propiedad industrial. Si existe una autoridad marcaria especializada en el conocimiento y resolución de las materias relativas precisamente a este "monopolio legal", y si hay tribunales especializados en estas cuestiones, es perjudicial desde el punto de vista de la seguridad jurídica que otros órganos - como son los de defensa de la libre competencia- se pronuncien sobre la constitución de la propiedad industrial y sus efectos. Lo anterior puede llevar incluso a decisiones contradictorias sobre una materia esencialmente idéntica pues, por ejemplo, la autoridad de marcas puede resolver que al concederse un registro marcario no se ha infringido ninguna de las prohibiciones del artículo 20 de la ley $\mathrm{N}^{\circ} 19.039$, al mismo tiempo que los órganos de defensa de la libre competencia resuelven que ese mismo registro importa un abuso del derecho ya que la marca en cuestión correspondería a un tercero que, con fama y notoriedad, la tiene registrada en el extranjero. Como señala un autor, refiriéndose a la represión de la competencia desleal en el derecho marcario, "el articulo $5^{\circ}$ del D.L. N $\mathrm{N}^{\circ} 211$ hace inaplicables sus disposiciones a la propiedad intelectual e industrial, lo que aparece como absolutamente raconable si se tiene presente que el 
derecho de autor y la propiedad industrial se desnaturalizarian y perderian su razón de ser ante una eventual privación de la exclusividad que otorgan a sus titulares. ${ }^{, 22}$

Este precedente, en fin, genera la mayor incertidumbre en los negocios jurídicos, al tiempo de que vulnera el derecho de propiedad que la Constitución reconoce sobre la marca comercial. El artículo $19 \mathrm{~N}^{\circ} 25$ de la Constitución Política garantiza la propiedad industrial sobre las marcas comerciales por el tiempo que señala la ley, haciendo aplicable a esta clase de propiedad lo dispuesto en los incisos $2^{\circ}, 3^{\circ}, 4^{\circ}$ y $5^{\circ}$ del artículo $19 \mathrm{~N}^{\circ} 24$ de la carta fundamental.

Pues bien, de acuerdo al inciso $3^{\circ}$ del artículo $19 \mathrm{~N}^{\circ} 24$, nadie puede ser privado de su propiedad, del bien sobre el que recae o de algunos de los atributos o facultades esenciales del dominio, sino en virtud de ley general o especial que autorice su expropiación por causa de utilidad pública. Sin embargo, como fundamento de su intervención y de la formulación del respectivo reproche, las Comisiones antimonopolios presuponen y dan por establecido, a priori, que el titular de la marca en Chile -requerido o denunciado- se ha apropiado indebidamente de una marca ajena, registrada en el extranjero; y para ello deben dar por establecido también, de hecho, que el verdadero dueño de esa marca es precisamente la empresa extranjera, no obstante estar vigente el registro de la marca en Chile. Lo anterior implica, simplemente, que en la práctica se impide al denunciado o requerido el ejercicio del derecho de propiedad sobre la marca, sin que exista ley expropiatoria.

Todas las cuestiones relativas al dominio sobre los bienes y aquéllas en que se disputa quién es el dueño de una cosa, no son materias que se encuentren bajo la competencia de los órganos de defensa de la libre competencia, de modo tal que no pueden dichos órganos decidir sobre ellas. Del mismo modo, las cuestiones relativas a la legitimidad o derecho para haber adquirido un registro marcario tampoco lo son. Quien estima que el titular de un derecho marcario lo ha adquirido en forma ilegítima, o sin haber tenido título para ello, debe reclamar la nulidad de ese registro ante el tribunal de marcas competente; pero estando vigente un registro marcario, o encontrándose en tramitación uno o más juicios de nulidad relativos a ese registro, ningún órgano del Estado puede emitir un pronunciamiento declarando que ha habido una apropiación de una marca ajena.

Podrá tal vez decirse que un pronunciamiento en tal sentido, por los organismos antimonopolios, tendría sólo un fin extra-marcario, tendiente a representar y/o sancionar únicamente una conducta que ha tenido por objeto impedir a un competidor su ingreso al mercado nacional (por lo que ese sería el único alcance de tales declaraciones). Sin embargo, tampoco es admisible que un órgano de defensa de la libre competencia dé por establecida una transgresión a las normas del D.L. 211, sobre la base de hechos o antecedentes previos (quién es el

${ }^{22}$ GARCiA-IIUTD OBRO AMUNÁTEGUI, Vladimir: "Tegislación sobre Propiedad Indtustrial", pp. 20 y 21. 
verdadero dueño de la marca y si se adquirió legítimamente o no) que se deben resolver por otros órganos públicos, como lo son los tribunales ordinarios de justicia y los tribunales marcarios.

\section{IV.- UNA PROPUESTA DE SOLUCIÓN; ADECUACIÓN DE LA NORMATIVA SOBRE PROPIEDAD INDUSTRIAL A LOS ACUERDOS INTERNACIONALES Y MEDIDAS COMPLEMENTARIAS.}

A partir del Acuerdo General sobre Aranceles Aduaneros y Comercio (GATT, del año 1947), y como consecuencia del proceso creciente y generalizado de globalización de los mercados que el tiempo ha generado, numerosas han sido las reuniones de negociación multilaterales de comercio tendientes a adecuar las normas del antedicho acuerdo a las exigencias y a la realidad del comercio internacional actual. Expresión de tales rondas negociadoras, y como resultado de ellas, lo fue el denominado "Acuerdo de Marrackech", del año 1994, por el cual los países miembros del GATT crearon la "Organización Mundial de Comercio" (OMC), incorporando expresamente al mismo la propiedad intelectual en cuanto disciplina de especial tratamiento y desarrollo por los países partícipes ${ }^{2.3}$.

Fue en la denominada "Ronda de Uruguay" en donde los países miembros destacaron la especial relevancia de la propiedad intelectual en el mundo globalizado de hoy, coincidiendo y reconociendo además la necesidad de confluir en un conjunto de normas, principios e instrumentos jurídicos de común aplicación en los sistemas normativos internos. Desde allí, las nuevas normas y principios en materia de propiedad intelectual quedaron plasmadas en el "Anexo $1 \mathrm{C}$ ", sobre "Aspectos de los Derechos de Propiedad Intelectual relacionados con el Comercio" (ADPIC), que trata de los derechos de autor, de las marcas de fábrica o de comercio, las indicaciones geográficas, los dibujos y modelos industriales, las patentes, esquemas de trazados de circuitos integrados y, por último, sobre la protección de la información no divulgada.

Nuestro país, en cuanto miembro del Acuerdo de la OMC y sus Anexos, debe entonces responder a la necesidad de actualizar y adecuar -entre otras- las normas de la Ley $\mathrm{N}^{\circ} 19.039$, conciliándola con los requerimientos expresos contenidos en aquel. Por ello, y encontrándose ya vencido el plazo que el mismo Acuerdo concedió a los países en vías de desarrollo ${ }^{24}$, se presenta ahora una buena e ineludible- oportunidad para introducir las modificaciones que, entre otras, permitan conciliar y armonizar definitivamente las normativas sobre marcas comerciales -por un lado- y libre competencia -por el otro-, hoy en aparente

23

23 Con fecha 17 de mayo de 1995 se publicó en el Diario Oficial el Decreto $N^{\circ} 16$ del Ministerio de Relaciones Exteriores, 24 que promulgó el acuerdo de Marrackech (OMC) y sus Acuerdos anexos 1A, 1B, 1C, 2 y 3.

24 Según el mismo Acuerdo, los países miembros en desarrollo podrian aplazar en cuatro años, contados desde el 01 de enero de 1996, la plena aplicación de sus disposiciones, debiendo adecuar en ese plazo la normativa interna. 
conflicto dada la amplísima interpretación que los organismos antimonopolios hacen del D.L. N²11, de 1973.

\section{1.- El uso de la marca comercial en la ley chilena.}

1.1.- El artículo 34 del Reglamento de la Ley $N^{\circ} 19.039$ señala que la utilización de la marca no será condición para su registro, vigencia o renovación.

Esta disposición reglamentaria ha incentivado de algún modo, a no dudarlo, un efecto práctico negativo en el tráfico comercial a nivel mundial. A consecuencia del desarrollo del comercio internacional y de la globalización creciente de la economía, las marcas comerciales han trascendido las fronteras de sus respectivos países de origen para ingresar vertiginosamente en los mercados extranjeros, distinguiendo los productos de los exportadores. Para ello, estos exportadores recurrían al registro de la marca en los mercados extranjeros en que decidían incursionar, lo que muchas veces se hacía imposible ante la existencia de un registro previo de la misma marca en el país respectivo, o de alguna otra claramente confundible con aquella. Esta situación, y haciendo salvedad en los casos de mera coincidencia, se originó simplemente porque un competidor deshonesto, conocedor del ingreso inminente de la marca extranjera al mercado interno, se apresuraba a registrarla a su nombre con el fin preciso de privar al titular extranjero de su marca.

Pues bien, esta práctica nefasta -aunque evidentemente no generalizada-, denominada por los autores como "piratería de marcas", ha llevado a los diversos países a adoptar las medidas necesarias de resguardo, tanto a nivel interno como a través de numerosos acuerdos internacionales. Asi, y no obstante que el mejor método de prevención contra la indicada práctica es la diligencia por parte de los titulares legitimos de una marca comercial ${ }^{25}$, la actual Ley $\mathrm{N}^{\circ} 19.039$ ha reconocido expresamente la real posibilidad de que un registro marcario se destine no ya a su identificación con algún producto, servicio o establecimiento comercial con presencia real en el mercado interno, sino más bien como medio de obtener ventajas indebidas en el marco de una competencia desleal. En tal sentido, pues, el artículo 20 letra j) prohíbe -y hace anulables- las marcas que sean "contrarias al orden público, a la moral y a las buenas costumbres, comprendidas en éstas los principios de competencia leal y ética mercantil" (el destacado es nuestro), actualizando e innovando expresamente respecto del artículo 23 letra K) del D.L. $N^{\circ} 958$ de 1931 , sobre Propiedad Industrial, que sólo hablaba de las marcas que fueran "contrarias a la moral, buenas costumbres, o al orden público". A lo anterior, además, debe añadirse lo

\footnotetext{
25.5 autor argentino Pedro Breuer Moreno, en su "Tratado de Marcas de Fäbrica y de Comercio", pp. 540 y ss., scñala:

"Teniendo en cuenta que el despojo de marcas en todos los países es consecuencia de la negligencia personal más que de los defectos de las leyes, no atribuye extrema gravedad a una situación que tiene, por lo general, un remedio fácil: diligencia."
} 
dispuesto por el artículo 6 bis del "Convenio de París para la Protección de la Propiedad Industrial”, promulgado en Chile en virtud del Decreto $\mathrm{N}^{\circ} 425$ de 08 de abril de 1991 (D.O. de 30 de septiembre de 1991); en él, se concede a los miembros de la unión -creada por el mismo Convenio- un plazo mínimo de cinco años para reclamar la anulación -por el titular extranjero- de una marca propia, notoriamente conocida, declarando además imprescriptible dicha acción en el caso de marcas registradas o utilizadas de mala fe.

En consecuencia, la actual normativa -nacional e internacional- consulta los mecanismos jurisdiccionales suficientes para una adecuada defensa frente a situaciones como las descritas (lo que reafirma lo que hemos señalado en capítulos anteriores, en cuanto a la inconveniencia e improcedencia de una intervención simultánea de los organismos antimonopolios en materias marcarias). Sin embargo, la mantención de un sistema marcario en donde el uso de la marca registrada no es requisito de su vigencia y ulterior renovación, no hace más que dejar abierta y perpetuar la posibilidad del mal uso y desnaturalización de la propiedad industrial, fomentada -en todo caso- por la pasividad o falta de diligencia del titular legítimo de la marca extranjera famosa y notoria.

En tal sentido, pues, si permanecemos con un sistema en donde el costo que representa registrar en Chile una marca extranjera ajena es notoriamente inferior al beneficio que una eventual negociación -con el titular extranjero- puede reportar, lo que se está haciendo es otorgar claros incentivos para perseverar en conductas de tal naturaleza, en vez de reprimirlas a priori mediante mecanismos disuasivos que aumenten significativamente el costo antedicho. Por lo mismo, la solución actual no sólo resulta inconveniente desde el punto de vista jurídico (al punto que los organismos antimonopolios se han visto incluso en la necesidad de reaccionar ante tales prácticas, contrariando -a nuestro entender- principios y normas expresas), sino que trasunta también una solución económicamente ineficaz. Por una parte, nada justifica la existencia de aquellas marcas vacías, estériles o infértiles, que no llegan jamás a asimilarse con algún producto en el mercado y que, por ende, no generan un beneficio o excedente social tangible (ni siquiera por la vía de las transacciones de marcas en el mercado); y por la otra, su sola existencia da pié a conductas reñidas con la ética comercial que, aunque aisladas, generan a la larga un mayor costo de transacción para el titular primigenio que pretende introducir sus productos en el país.

1.2.- Pues bien, un elemento común a los diversos dictámenes y resoluciones de los organismos antimonopolios -en cuanto a la materia que aquí se trata-radica, en la generalidad de los casos, en la falta de uso de la marca comercial por parte de su titular en Chile. Reiteradamente, pues, se sostiene que el registro marcario atenta contra la libre competencia por impedir el ingreso de la empresa o producto extranjero reivindicado por esa marca, sin que siquiera se identifique con otros 
productos o servicios en el mercado interno. Así por ejemplo, han señalado estos organismos:

- “... la protección para el uso exclusivo de la marca, en las condiciones que la Ley de Propiedad Industrial establece, no llega a amparar situaciones extremas como es el registro de marcas que no sean utilizadas por el titular, sino sólo para los efectos de impedir su utilización a quien es conocido en la generalidad de los países..."

- "Que, en efecto, la solicitud de la compañía... de proceder a solicitar inscripción precisamente de las marcas... y ... y de la etiqueta..., en la misma época en que tuvo conocimiento de que... iba a iniciar la comercialización de fósforos de esas mismas marcas, demuestra inequívocamente que su única finalidad era entorpecer dicha comercialización, objetivo que aparece corroborado con su conducta posterior a dichas inscripciones, ya que es un hecho público y notorio que la compañía denunciada no ha comercializado, con incidencia en el mercado, los productos que registró en conformidad a la Ley de Marca" ${ }^{27}$.

En consecuencia, una alternativa de solución al problema planteado se encuentra en la posibilidad de legislar respecto de la implantación, en cuanto obligación del titular de la marca, del uso efectivo de la misma según su clasificación y en un período determinado (consultando siempre los casos de legitima excepción), de manera tal que cada marca tenga su expresión concreta en un producto o servicio que se transa en el mercado. De esta forma, todo aquel que pretenda valerse de la marca comercial para fines distintos de aquellos que le son propios (v. gr. como herramienta de futura negociación con quien pretenda un mejor derecho sobre ella) deberá asumir el costo de ello. En otros términos, y sin perjuicio del pago de las tasas de solicitud, concesión y mantención de la marca, su titular se verá obligado a efectuar -so pena de caducidad- inversiones en tecnología, investigación o bienes de capital en general, para dar concreción efectiva en el mercado nacional a los derechos que le confiere su marca.

Lo anterior implicará, pues, que el uso público y ostensible de la marca restringe substancialmente la posibilidad de que aquellos terceros que no ejercieron oportunamente los derechos de prioridad y oposición que confieren el artículo 4 del Convenio de París y la Ley $\mathrm{N}^{\circ} 19.039$, respectivamente, aleguen luego un mejor derecho sobre la misma marca; máxime cuando ésta ha sido válidamente constituida y se mantiene vigente. En otros términos, el interés de los terceros de impedir que la marca extranjera -respecto de la que alegan exclusividad- siga siendo utilizada en el mercado interno no se enfrentará ya a un simple derecho registral o formal, sino que deberá ser ponderado y analizado -por los tribunales marcarios- a la luz de los derechos que esa marca disputada le confiere a un competidor que

\footnotetext{
${ }^{26}$ Informe y Requerimiento del Fiscal Nacional Tíconómico; Ord. N²70, de 01 de septiembre de 1998. 27

Comisión Resolutiva; Res. N¹69 de 28 de marzo de 1984
} 
tiene una activa presencia en el mercado, con productos o servicios que son notorios y conocidos por el segmento de público que habitualmente los consume o utiliza, respectivamente ${ }^{28}$. Por su parte, y en lo que concierne a la competencia de los organismos antimonopolios, toda posible infracción a la libre competencia -que surja precisamente con ocasión de la competencia derivada del uso efectivo de una marca disputada- podrá ser estudiada y acreditada en virtud de elementos concretos y palpables, representados por bienes, productos o servicios con presencia actual en el mercado y circunscrita a ese específico marco, sin intervenir en el ámbito exclusivo y excluyente de la normativa sobre propiedad industrial.

En todo caso, para establecer en Chile el requisito del uso de la marca debe tenerse en cuenta, necesariamente, los dispuesto en el Acuerdo anexo 1C (ADPIC), que en su artículo $15 \mathrm{~N}^{\circ}$ s. 3 y 4 señala:

- "3. Los Miembros podrán supeditar al uso la posibilidad de registro. No obstante, el uso efectivo de una marca de fábrica o de comercio no será condición para la presentación de una solicitud de registro. No se denegará ninguna solicitud por el solo motivo de que el uso pretendido no ha tenido lugar antes de la expiración de un período de tres años contado a partir de la fecha de la solicitud."

"4. La naturaleza del producto o servicio al que la marca de fábrica o de comercio ha de aplicarse no será en ningún caso obstáculo para el registro de la marca."

Luego, el artículo 19 del mismo acuerdo prescribe:

- "1. Si para mantener el registro se exige el uso, el registro sólo podrá anularse después de un período ininterrumpido de tres años como mínimo, de falta de uso, a menos que el titular de la marca de fábrica o de comercio demuestre que hubo para ello razones válidas basadas en la existencia de obstáculos a dicho uso. Se reconocerán como razones válidas de falta de uso las circunstancias que surjan independientemente de la voluntad del titular de la marca y que constituyan un obstáculo al uso de la misma, como las restricciones a la importación u otros requisitos oficiales impuestos a los bienes o servicios protegidos por la marca.

"2. Cuando esté controlada por el titular, se considerará que la utilización de una marca de fábrica o de comercio por otra persona constituye uso de la marca a los efectos de mantener el registro."

1.3.- Por último, y a fin de centrar clara y definitivamente en el ámbito del derecho marcario los conflictos surgidos entre marcas extranjeras notorias -por una parte- y los registros idénticos o similares en Chile -por la otra-, resulta conveniente incorporar expresamente a la Ley $\mathrm{N}^{\circ} 19.039$ lo dispuesto por el artículo 16 de los ADPIC, que a su turno se remiten al artículo 6 bis del Convenio de París.

${ }^{28}$ El concepto de "sector pertinente del público" fue acuñado por el artículo 16 de los ADPIC. 


\section{2.- Las recientes iniciativas legislativas en torno a la adecuación y actualización de la normativa interna sobre propiedad industrial.}

2.1. - Con fecha 20 de octubre de 1999, se ingresó en la oficina de partes de la Cámara de Diputados de Chile ${ }^{29}$ el Proyecto de Ley que modifica la Ley N¹9.039 y establece normas aplicables a los privilegios industriales y protección de derechos de propiedad industrial, proyecto éste que recoge, de consiguiente, el mandato de los Acuerdos Multilaterales adoptados en el seno de la OMC -vinculantes para Chile- para ajustar a sus disposiciones y principios las normativas internas de los respectivos Estados Miembros. El precitado proyecto de ley se encuentra actualmente en su segundo trámite constitucional.

En el mensaje del Proyecto referido, y en lo que concierne a los fundamentos de la iniciativa que le da origen, se hace especial mención a la necesidad de adecuar la legislación interna sobre propiedad industrial a las normas del Acuerdo de Marrackech, destacándose además el plazo que para tal efecto se estableció en el mismo Acuerdo ${ }^{31}$. Del mismo modo, el proyecto contiene modificaciones destinadas a concordar la normativa en actual vigencia con el Convenio de París para la Protección de la Propiedad Industrial, aplicable en Chile desde el año 1991. Dice en esta parte el Mensaje:

- "II. 2. Necesidad de adecuación de legislación interna.

"La reforma que dicho instrumento multilateral impone, supone adecuar, entre otros cuerpos normativos, la Ley $N^{\circ} 19.039$, relativa a las normas aplicables a los privilegios industriales y protección de los derechos de propiedad industrial, publicada en el Diario Oficial de fecha 25 de enero de 1991, de conformidad con las exigencias y requerimientos no recogidos por dicha Ley y contemplados por este Acuerdo vinculante para Chile.

“... Chile, como todo país Miembro en desarrollo, está habilitado para aplazar en cuatro años, a partir del 1 de enero de 1996, la aplicación del Acuerdo, debiendo disponer de una legislación vigente acorde con las obligaciones impuestas, a partir del 1 de enero del año 2000." Mensaje:

Luego, y precisando el propósito de la iniciativa en cuestión, agrega el

- "Asimismo, este proyecto de ley introduce algunas modificaciones destinadas a completar y concordar de manera coherente la actual Ley en vigencia con el Convenio de París, de plena aplicación en Chile desde el año 1991. Igualmente, se proponen ciertas modificaciones respecto de determinadas materias que, tanto la experiencia como la práctica de su aplicación, desde el año 1991 a la

\footnotetext{
${ }^{29}$ Boletin No2416-03, Caman de Diputados.

${ }^{30}$ Senado, Legislatura $N^{\circ} 347$ ordinaria.

${ }^{31}$ Ver nota $\mathrm{N}^{2} 23$.
} 
fecha, han demostrado ser necesarias para una más adecuada y eficaz institucionalidad en materia de propiedad Industrial."

Respecto del contenido del Proyecto de Ley, pueden distinguirse en él los siguientes aspectos principales:

\section{A) Modificaciones formales a la Ley $N^{\circ} 19.039$ :}

Se pretende por esta vía corregir la estructura y la sistemática de la Ley $\mathrm{N}^{\circ} 19.039$, "dotándola de un lenguaje técnico y jurídico más depurado, de conformidad con los modernos cánones y la actual y común terminología internacional desarrollada en el ámbito de la propiedad intelectual."

Concretamente, lo que aquí se propone es lo siguiente:

a. Agilizar, racionalizar y perfeccionar los procedimientos de solicitud y concesión de derechos industriales y;

b. Adecuar los derechos industriales a los estándares internacionalmente aceptados.

\section{B) Modificaciones substanciales al régimen de marcas comerciales:}

a. En primer término, se propone una nueva definición de marca, eliminando aquellos elementos ajenos a la esencia de los signos marcarios y agregando otros que se estiman indispensables para una correcta conceptualización de los mismos.

b. Se consagra el derecho de prioridad contemplado en el artículo 4 del Convenio de París;

c. Se precisa la accesoriedad de las frases de propaganda;

d. Se precisan también los derechos que confiere el registro marcario;

e. Se desvincula al signo distintivo de la referencia general que se hace respecto de la clase a que pertenece, debiendo hacerse las relaciones entre productos y servicios específicos y determinados;

f. Se regula la marca notoria extranjera según lo que establecen los números 2 y 3 del artículo 16 de los ADPIC;

g. Se restringe la aplicación del principio de especialidad respecto de marcas notoriamente conocidas, en la medida que exista algún riesgo de asociación entre ésta última y los productos o servicios a distinguir por el signo solicitado;

h. Se establece la incompatibilidad entre las marcas comerciales y las indicaciones geográficas; $y$

i. Se establece la caducidad de la marca por falta de acceso real y efectivo de la misma en el territorio nacional.

C) El Proyecto de Ley en actual estudio contempla entonces, expresamente, la obligación de uso efectivo de la marca por su titular, concretando así la naturaleza y finalidad de los signos marcarios y la indisoluble relación que existe 
entre éstos, el producto o servicio de que se trate y el mercado en el cual se transan $\mathrm{u}$ ofrecen. Dice en esta parte el Mensaje del Ejecutivo:

- "Esta institución busca impedir el bloqueo del sistema de protección marcaria producto de la saturación registral de meros derechos formales. Para ello se impone al titular registral la carga de hacer uso de su signo, con el objeto de garantizar que todo registro cuente con un producto o servicio efectivamente transado en el mercado, sin perjuicio de que existan causas válidas que justifiquen el no uso de la misma.

"Esta institución ha sido incorporada a la Ley $\mathrm{N}^{\circ} 19.039$, guardando la debida corresprndencia y armonía con el ordenamiento jurídico nacional y de conformidad on lo expresamente establecido por los acuerdos ADPIC y los estándares ir turnacionales vigentes."

Estas son, pues, las motivaciones del Ejecutivo para imponer la obligación de uso de la marca comercial. Sin embargo, en lo que a este trabajo de investigación concierne y retomando lo que señaláramos en el párrafo $1^{\circ}$ anterior, a las razones dadas en el Mensaje del Proyecto de Ley debemos agregar nosotros aquellas señaladas en el apartado 1.2. del antedicho parágrafo, tendientes a circunscribir las normas del D.L. $N^{\circ} 211$-por un lado- y las contenidas en la Ley $N^{\circ} 19.039$-por el otro- dentro de sus respectivos y específicos ámbitos substantivos, orgánicos y procedimentales.

D) Remitiéndonos ahora al cuerpo del Proyecto de Ley, y concentrándonos siempre en el deber de uso de la marca comercial, éste se incorpora expresamente por el $\mathrm{N}^{\circ} 18$ del artículo único del Proyecto, que a su turno intercala dos nuevos artículos ( 23 bis $C$ y 23 bis D) a la Ley $N^{\circ} 19.039$. Sus textos respectivos son del tenor siguiente:

- "Artículo 23 bis C.- Si a contar del quinto año a partir de la fecha de concesión del registro, la marca no hubiese sido objeto de un uso real y efectivo dentro del territorio nacional, por el titular o por un tercero con su consentimiento expreso, para los productos, servicios o establecimiento comercial y/o industrial, para los cuales haya sido concebida; o si dicho uso se hubiese suspendido de forma ininterrumpida por el mismo período de tiempo, ésta incurrirá en una causal de caducidad. Esta podrá alegarse mediante el ejercicio de la acción pertinente, salvo que existan razones válidas que justifiquen el no uso de la misma.

"Se considerarán como razones válidas de falta de uso, las circunstancias que surjan independientemente de la voluntad del titular de la marca y que constituyan un obstáculo al uso de la misma.

"En los procedimientos de caducidad por falta de uso, corresponderá al demandado probar el uso real y efectivo de la marca.",32

\footnotetext{
${ }^{32}$ El texto de este artículo no fue objeto de modificaciones durante la su tramitación del proyecto ante la Cámara de Diputados, y fuc informado favorablemente por la Comisión de Économia del Senado en segundo trámite constitucional (Primer Informe, de fecha 27 de Agosto de 2002).
} 
"Artículo 23 bis d.- Para efectos del artículo anterior, se considerará como uso:

a) La utilización de la marca de manera diferente sin que por ello difiera sustancialmente de la forma en que originalmente fue registrada.

b) La utilización de la marca para distinguir productos y servicios destinados única y exclusivamente con fines de exportación.

"De igual manera, la utilización de una marca para un producto, servicio o establecimiento comercial y/o industrial servirá para acreditar el uso respecto de los productos y servicios relacionados pertenecientes o no a la misma clase del Clasificador Internacional., 33

Por su parte, el $\mathrm{N}^{\circ} 7$ del artículo único del proyecto substituye el artículo 17 de la Ley $N^{\circ} 19.039$ por el siguiente:

- "Artículo 17.- Los procedimientos de oposición, nulidad, caducidad por falta de uso del registro o de transferencias, así como cualquier reclamación relativa a su validez o efectos, o a los derechos de propiedad industrial en general, se substanciarán ante el Jefe del Departamento de Propiedad Industrial, ajustándose a las formalidades que se establecen en esta Ley y a las que disponga el reglamento. ${ }^{34}$

"El fallo que dicte será fundado y en su forma deberá atenerse, en cuanto sea posible, a lo dispuesto por el artículo 170 del Código de Procedimiento Civil."

\section{V.- CONCLUSIONES.}

Hemos descrito y analizado el conflicto normativo que hasta hoy se mantiene latente en nuestro ordenamiento interno, y hemos propuesto al respecto las alternativas de posible solución para armonizar la vigencia, coexistencia y plena aplicación de los estatutos jurídicos que regulan la propiedad industrial -por una parte- y la defensa de la libre competencia -por la otra-.

A modo de compendio de los temas tratados en esta investigación, y como resultado de la misma, podemos consignar entonces las conclusiones siguientes:

1.- Las facultades que el D.L. 211 concede a los órganos de defensa de libre competencia para prevenir, investigar, corregir y reprimir los atentados a la libre competencia (a:tículo $6^{\circ}$ ), en cuanto ellos importan una intervención del Estado en actividades de particulares, deben entenderse circunscritas y limitadas por el bien jurídico que se trata de defender. Tratándose de las facultades represivas que la Ley otorga a estos órganos, lo dicho se traduce en la práctica en que sólo podrán reprimirse aquellos actos o hechos que objetivamente lesionen o pongan en peligro el bien jurídico, que es la libre competencia y que estén descritos como

\footnotetext{
33 En su tramitación ante la Cámara de Diputados, cl encabezado de esta articulo fue modificado de la siguiente forma:

"Anticula 23 bir D.- No obslante lo señalado en el articallo anterior, se considerari como uso:"

Artículo no modificado en el texto aprobado por la Cámara, en primer trámite constitucional.
} 
delito en el D.L. 211. Es el daño al bien jurídico o su objetiva puesta en peligro la que justifica la intervención punitiva o represiva de los órganos de defensa de la libre competencia; la mera intención de impedir o restringir la libre competencia, si no lesiona o pone en peligro el bien jurídico, no puede ser objeto de medidas coercitivas que afecten la libertad de los particulares.

2.- La marca comercial confiere a su titular un derecho exclusivo de utilización y aplicación, incluyendo el derecho a oponerse a su uso por parte de terceros ajenos a la marca, particularidad ésta sugiere la existencia de lo que en doctrina se denomina "monopolio legal".

La existencia de este monopolio tiene un reconocimiento directo en la Constitución Política de la República de 1980 y en la Ley. Por ello, el ser titular de una marca comercial no importa una violación de los preceptos del D.L. 211, los que no pueden aplicarse a situaciones en que es la ley la que confiere un monopolio.

El ejercicio por el titular del registro marcario de las facultades y derechos que le concede su privilegio, no puede en caso alguno ser considerado una conducta ilícita, de aquellas contempladas en los artículos $1^{\circ}$ y $2^{\circ}$ del D.L. 211. Entre las facultades referidas, está precisamente la de impedir que otro use la marca que se encuentra registrada a nombre del titular, lo que se efectúa mediante la interposición de las acciones judiciales que la ley sobre propiedad industrial establece. Mientras se encuentre vigente un registro marcario a nombre de una persona, las facultades que el D.L. 211 concede a los órganos de control antimonopolios no pueden extenderse a la posibilidad de impedirle a ese titular el uso de la marca registrada, o a restringir o impedir el ejercicio de los derechos que de ella dimanan.

3.- Resulta improcedente un pronunciamiento a priori de los órganos defensa de la libre competencia respecto de la legitimidad o ilegitimidad de las marcas comerciales y, por lo tanto, sobre la legitimidad o ilegitimidad del ejercicio de las acciones judiciales que emanan de la marca comercial. Tal pronunciamiento implica un prejuzgamiento de materias que son específicas del registro, cuyo conocimiento y resolución está entregado por la ley al tribunal marcario respectivo.

4.- La tesis del "abuso del derecho", como premisa de justificación en el actuar de los organismos antimonopolios frente a la normativa sobre propiedad industrial e intelectual, resulta insuficiente, imprecisa y riesgosa, poniéndose en riesgo la seguridad del tráfico jurídico. La protección que la Constitución y la Ley otorgan al derecho de propiedad industrial tiene un amplio rango, de modo tal que el concepto de "abuso del derecho" o no tiene cabida, o bien debe entenderse en un contexto muy estricto y limitado, o sea, entendido y aplicado sólo dentro de su ámbito lógico: el de las marcas o propiedad industrial. Las situaciones que los organismos antimonopolios califican como un "abuso del derecho", se encuadran en todo caso dentro de las causales de nulidad del artículo 20 de la ley No 19.039 . 
5.- Si la competencia desleal se produce con ocasión de un conflicto marcario, en donde dos o más personas se arrogan titularidad o, a lo menos, un mejor derecho sobre la marca, son los tribunales marcarios los llamados a conocer y resolver tales conflictos, más no los organismos antimonopolios. Así se desprende del mandato amplio del artículo 17 inciso $1^{\circ}$ de la Ley $\mathrm{N}^{\circ} 19.039$.

6.- Los terceros a quienes pueda afectar un privilegio industrial están suficientemente resguardados en sus derechos por los mecanismos que la legislación marcaria establece. Por ello, el solo hecho de solicitar una marca comercial determinada y obtener el registro de ella no podrá nunca ser un acto que importe el "abuso de un derecho". Tampoco puede ser calificado de abusivo el hecho de que la autoridad marcaria acoja una solicitud de registro. Si no hay abuso al solicitarse el registro de una marca, ni al concederse el privilegio sin oposición de terceros, tampoco lo hay cuando el titular del registro vigente ejerce las facultades que son inherentes al dominio sobre él.

7.- La obligación de uso de la marca comercial restringe substancialmente la posibilidad de que aquellos terceros que no ejercieron oportunamente los derechos de prioridad y oposición que confieren el artículo 4 del Convenio de París y la Ley $\mathrm{N}^{\circ} 19.039$, respectivamente, aleguen luego un mejor derecho sobre la misma marca.

En lo que concierne a la competencia de los organismos antimonopolios, toda posible infracción a la libre competencia -surgida con ocasión del uso efectivo de una marca disputada- podrá ser estudiada y acreditada en virtud de elementos concretos y palpables, representados por bienes, productos o servicios con presencia actual en el mercado y circunscrita a ese específico marco, sin intervenir en el ámbito exclusivo y excluyente de la normativa sobre propiedad industrial.

8.- La acción para reclamar ante los órganos de defensa de la libre competencia debe estar sujeta a extinción por el transcurso del tiempo, ante la inactividad del interesado. Igualmente, la acción de los órganos del Estado para reprimir determinados actos o hechos está sujeta también a extinguirse en el tiempo. A falta de disposición especial, debe aplicarse el plazo general y máximo que el artículo 94 del Código Penal establece para las acciones penales por simples delitos. 